UDK 336.741.242:336.113

Tetiana Gorokhova, PhD (Economics), Associate Professor, Priazovskyi State Technical University, The Department of Marketing and Business-Administration, Mariupol, ORCID iD: https://orcid.org/0000-0003-0435-5047, e-mail: gorokhova_t_v@pstu.edu

https://doi.org/10.29038/2786-4618-2021-03-14-21

\title{
THE TRANSFORMATION OF BUSINESS PROCESSES IN CONDITIONS OF DIGITALIZATION OF ECONOMIC SYSTEMS
}

The article considers to the aspects of identifying key directions that determine the successful functioning of an organization in the context of the digital economy development. The key areas of business transformation have been identified, allowing flexible restructuring of the company management process. Methods and techniques for assessing digital transformation in organizations that are tested for both quantitative and qualitative indicators have been considered. It has been proven that considering digital transformation is advisable not only in the context of studying business models in the development of digital technologies, but also from the point of view of what economic effects are achieved through digital transformation and how justified it.

Key words: digital transformation, business model, digitalization, business management, methods.

Горохова Татьяна, кандидат экономических наук, доцент, ГВУЗ «Приазовский государственный технический университет», г. Мариуполь

\section{ТРАНСФОРМАЦИЯ БИЗНЕС-ПРОЦЕССОВ В УСЛОВИЯХ ДИДЖИТАЛИЗАЦИИ ЭКОНОМИЧЕСКИХ СИСТЕМ}

В статье рассматриваются аспекты определения ключевых направлений, определяющих успешное функционирование организации в контексте развития цифровой экономики. Определены ключевые направления трансформации бизнеса, позволяющие гибко реструктурировать процесс управления компанией. Рассмотрены методы и приемы оценки цифровой трансформации в организациях, с учетом как по количественным, так и по качественным показателям. Доказано, что рассмотрение цифровой трансформации целесообразно не только в контексте изучения бизнес-моделей развития цифровых технологий, но и с точки зрения того, какие экономические эффекты достигаются за счет цифровой трансформации и насколько это оправдано.

Ключевые слова: диджитал трансформация, бизнес модель, диджитализация, управление бизнесом, методы.

Горохова Тетяна, кандидат економічних наук, доцент, ДВНЗ «Приазовський державний технічний університет», м. Маріуполь

\section{ТРАНСФОРМАЦІЯ БІЗНЕС -ПРОЦЕСІВ В УМОВАХ ДІДЖИТАЛІЗАЦІЇ ЕКОНОМІЧНИХ СИСТЕМ}

Через процеси діджиталізації економічних систем постає питання ефективності трансформації бізнес процесів та стратегічних напрямів управління компаніями.

У даній статті проаналізовано та визначено, що в реальному секторі економіки цифрова трансформація бізнес-систем в України, здійснюється у напрямках впровадження цифрових систем в управлінські процеси, створення цифрової архітектури, вирішення питань інформаційної безпеки, визначення роботи 3 цифровими 
активами у рамках правового поля, впровадження смарт-контрактів у цифровому середовищі. Досліджено теоретико-методичні аспекти визначення цифрової трансформації та ії̈ впливу на управління бізнес-процесами.

У статті наведено приклади ключових характеристик хмарних обчислень у бізнесі відносяться, такі як: самообслуговування на вимогу; широкосмуговий доступ; наявність пулу обчислювальних ресурсів; здатність швидко переналаштовувати бізнес -процеси; облік споживання обчислювальної потужності.

Визначено, що для просування продуктів на цифровому ринку керівництво компанії використовує бізнес аналітику та інструменти для роботи з Big Data.

Автором розглянуто та проаналізовано визнані методологічні підходи та невизначено широкі групи методологічних рішень. У статті описано різноманітність методологічних підходів 3 їх рішеннями та недоліками. Окреслено, що оцінювані показники ефективності цифрової трансформації безпосередньо залежать від обраної моделі оцінки. Визначено, що аналіз цифрової трансформації тільки в контексті інвестиційного аналізу або бухгалтерської вартості активів може призвести до неправильного тлумачення ефекту, оцінюючи проект як фінансово невигідний.

Запропоновано розглядати цифрову трансформацію не тільки в контексті вивчення вдосконалення бізнес моделей у рамках розвитку цифрових технологій, але і з прикладної точки зору: які економічні ефекти досягаються завдяки цифровій трансформації і наскільки це виправдано з точки зору витрат.

Ключові слова: інноваційний розвиток підприємств, цифрова економіка, планування, організація, мотивація, контроль.

Introduction. Nowadays, the current state of economic reality can be described as a transitional one: economic entities are taking steps in the direction from the traditional to the digital form of the economy, which is characterized by an increase in interest in the use of information technologies, as well as the growing popularity of operating with digital data in the process of the activity. A feature of this process in the current situation is the combination of the high rate of emergence of new digital solutions with slow development by business entities in the decision-making process. Such a lag in the introduction of digital technologies into the business processes is due to the following internal factors: the unwillingness of both personnel and company management to reorient in accordance with the new operating conditions, as well as an insufficient level of infrastructure development. With regard to external factors of influence, it is worth talking about the low level of elaboration and effectiveness of legislative regulation related to the new sphere of the emergence of the rights and obligations of subjects. It is important to note that the application of a systematic approach to the creation of a comprehensive legal framework will create favorable conditions for the growth of the attractiveness of digital tools in the context of their use by participants in economic processes. However, these changes will be feasible only under the complete understanding conditions of the specifics and relevance of the emerging system's functioning.

Analysis of recent research and publications. Problems of technology influence on business process studied J. Scott Brennan, D. Kreis, J. Bloomberg and J. Manciniand others. Among the domestic ones we can single out V. Verba, M. Dyba, O. Gusev, S. Legominov, A. Notarin, S. Filipov, N. Pylypiv and others.

Selection of previously unsolved parts of the overall problem. The relevance of this scientific research is associated with the current situation in Ukraine and in the world, which stimulated digitalization processes in both medium and small business. In the conditions caused by the pandemic, the economy began to actively transform, the digital economy gained more importance, which caused many changes in the structure of organizations.

Results of research. The rapidly developing digital economy is rapidly changing business models, requiring the company's management to restructure all business processes to achieve competitiveness both in the current and long term. Ukraine government has adopted a law «On stimulating the development of the digital economy» № 1667-IX. The law is designed to create favorable conditions for conducting innovative business in Ukraine, building digital infrastructure, attracting investment and professionals.

To stimulate the development of the digital economy, the document introduces the legal regime "Diya City" and defines the organizational, legal, and financial principles of its operation. This legal regime provides for special tax conditions, which will be determined by the Tax Code of Ukraine. The relevant bill is currently being drafted by the Verkhovna Rada to fulfill the tasks set out in Presidential Decree № 371 "On Measures to Create Favorable Conditions for the Development of the IT Industry in Ukraine". 
Special tax conditions will apply to companies - residents of "Diya City". A legal entity registered on the territory of Ukraine that meets a number of requirements specified in the document may become such a resident. Resident status is granted by "Diya City" to an authorized central executive body that ensures the implementation of state policy in the digital economy. The law defines the issues related to the acquisition and loss of this status.

Information on companies that have or have been a resident of "Diya City" is contained in the electronic register of "Diya City", which is open and published on the Internet.

The legal regime of "Diya City" is established for a period of not less than 25 years from the date of entry in the register of its first resident.

The law also contains provisions related to temporary incapacity for work and social guarantees for gig specialists, their compulsory state social insurance, as well as the intellectual property right to an object created in connection with the execution of a gig contract [1].

Nowadays, in the real sector of the economy, the digital transformation of business systems that are currently being formed in the industry of Ukraine is carried out in several directions:

1.Implementation of information technologies/systems that ensure effective interaction with digital services of public authorities;

2.The formation of a digital architecture that supports various business models in distributed networks;

3.Solving issues of information security of an enterprise integrated into a business structure, accompanied by the introduction of a full-time position of a digital director;

4.Determination of the procedure for working with digital assets, the legal status of service digital products;

5.Effective support of smart contracts, digital projects related to the security of big data, and service blockchain solutions.

Summarizing the approaches of IT solutions specialists, consultants, and practitioners, we will understand the term "digital transformation (DT)" - the transformation of business models and processes based on investment in high information / innovative technologies that provide customization of production processes in relation to industrial enterprises [2]. The trend towards individualized consumption for small and medium-sized businesses involves the use of a service factory model.

The trend in the reengineering of the organization's business processes is the introduction into the practice of computer algorithms that make it possible to manage big data about counterparties owning any assets [3]. Smart contracts transform the financial sphere of an organization's activities since they provide an opportunity to form a corporate securities market without the participation of a number of social institutions of society.

Enterprise information security issues are resolved automatically by eliminating the corruption component through the use of blockchain technologies. Blockchain refers to a database that is a continuous chain of blocks and is stored simultaneously on multiple computers.

From a legal point of view, the digital transformation of business directly affects such a branch of law as civil, and directly contractual law. For participants in technological chains, the issue of distribution of public and private keys becomes relevant when carrying out mutual settlements for transactions. Platforms "Blockchain", "Etherium" as an interaction platform ensure the self-execution of contracts when certain circumstances occur.

In jurisprudence, there is a surge of interest in the issues of legal support of transactions between business entities in the digital environment. However, it seems problematic to completely digitize contracts, if only due to the fact that a number of definitions (reasonable terms, false assurances, limited legal capacity, etc.) are rather difficult to describe in a programming language. It should be recognized that the scope of application of smart contracts still remains limited due to this circumstance [3].

The observed trend in the desire to legislatively regulate the transfer of assets subject to state registration from one industrial organization to another for use in the virtual world and manipulations on interaction platforms affects the need to determine the jurisdiction of a "smart" contract, transparency of data in transactions in the implementation of cross-border transactions [4]. 
The next trend in digital business transformation is the standardization of IT processes in an organization through the use of cloud computing. Cloud computing is generally understood as a model for providing a ubiquitous network (Internet) on-demand access to a shared pool of configurable computing resources that can be quickly provisioned and implemented with minimal administrative effort when interacting with a service provider. The key characteristics of cloud computing in business include:

- $\quad$ self-service on demand;

- broadband access;

- availability of a pool of computing resources;

- $\quad$ the ability to quickly reconfigure business processes;

- $\quad$ accounting for the consumption of computing power.

The service models for cloud computing are infrastructure as a service, platform as a service, and software as a service. The trend for most organizations is to use the public cloud to advertise their products and services. To promote products on the digital market, the company's management uses business intelligence and tools to work with Big Data. Big data is structured and unstructured data of enormous volumes and variability that is efficiently processed by horizontally scalable software tools.

The leaders in investments in big data technologies remain representatives of companies with discrete or continuous production. The main emphasis in using business intelligence tools by 2020 was on the preparation of analytical reports and data warehouse management.

The digital transformation of business implies that crowdfunding is used to finance innovative projects, start-ups and small businesses, which means the pooling of financial resources on a voluntary basis via the Internet without the need for a return.

Consideration of digital transformation is advisable not only in the context of studying the improvement of business models within the framework of developing digital technologies, but also from an applied point of view: what economic effects are achieved due to digital transformation and how much it is justified from the point of view of costs.

First of all, it should be noted that in order to assess digital transformation, the mandatory use of a special analytical apparatus is not required: it is possible to use traditional methods of economic and qualitative analysis. At the same time, the key difficulty in choosing assessment methods is to achieve a balance between the accuracy of the information being processed, the completeness of cause-and-effect relationships, and the quality of the mathematical apparatus. Thus, every digital transformation analysis requires equality of the weights between the three parameters mentioned. At the same time, there is no universal method for assessing digital transformation - combinations of different methods are used, depending on the situation.

Author analyzed examined 6 recognized methodological approaches and 2 indefinitely broad groups of methodological solutions. The variety of methodological approaches with their solutions and disadvantages were described (Table 1).

The overall goal is, in fact, to assess the effectiveness of digital transformation. However, this is too general a term. Such effectiveness is measured in terms of indicators inherent in each separately taken methodological approach. The assessed indicators of digital transformation effectiveness directly depend on the selected assessment model.

From this analyze, we can do the next conclusions:

There are no universal methods for assessing the effectiveness of DT due to the lack of universally applicable indicators studied during the assessment. This state of affairs is dictated by the abundance of methodological approaches to the assessment of DT.

The results of the assessment are sensitive to the chosen assessment methodology. By changing the methodology, we deliberately change the final grade. The choice of an analyst can predetermine the set of analyzed parameters.

When using quantitative assessment methods, as the name suggests, quantitative economic and economic indicators are investigated. Such as balance sheet data, changes in the value of transformed assets, investment calculations or cashflow calculations for transforming business processes. 
Groups and main characteristics of methodological approaches

\begin{tabular}{|c|c|c|c|c|}
\hline № & $\begin{array}{l}\text { Name of the } \\
\text { methodological } \\
\text { approach or } \\
\text { methods }\end{array}$ & $\begin{array}{c}\text { The essence of a } \\
\text { methodological solution }\end{array}$ & $\begin{array}{l}\text { Disadvantages of the } \\
\text { methodological } \\
\text { approach }\end{array}$ & $\begin{array}{l}\text { Main sources of } \\
\text { information }\end{array}$ \\
\hline 1 & $\begin{array}{l}\text { Accounting } \\
\text { methods }\end{array}$ & $\begin{array}{l}\text { Calculation of costs for } \\
\text { conducting DT, } \\
\text { subsequent revaluation of } \\
\text { assets }\end{array}$ & $\begin{array}{l}\text { Synergistic, intangible } \\
\text { indicators are not } \\
\text { considered. }\end{array}$ & $\begin{array}{l}\text { Accounting } \\
\text { documentation, list } \\
\text { of costs }\end{array}$ \\
\hline 2 & $\begin{array}{l}\text { Investment analysis } \\
\text { methods }\end{array}$ & $\begin{array}{l}\text { Detailed assessment of } \\
\text { cash flows and } \\
\text { profitability } \\
\text { characteristics influenced } \\
\text { by DT }\end{array}$ & $\begin{array}{l}\text { Costs and profitability } \\
\text { growth are not } \\
\text { compared, the } \\
\text { specifics of the } \\
\text { business case are not } \\
\text { considered analytically }\end{array}$ & $\begin{array}{l}\text { Investment analysis } \\
\text { parameters, } \\
\text { implementation } \\
\text { projects }\end{array}$ \\
\hline 3 & Scoring methods & $\begin{array}{l}\text { Scoring of business } \\
\text { processes involved in DT, } \\
\text { scoring of trends dictated } \\
\text { by DT }\end{array}$ & $\begin{array}{l}\text { Complex and } \\
\text { resource-intensive } \\
\text { solutions requiring a } \\
\text { large analytical base }\end{array}$ & $\begin{array}{l}\text { Motivated } \\
\text { assignment of } \\
\text { analytical ratings } \\
\text { for the processes } \\
\text { involved }\end{array}$ \\
\hline 4 & $\begin{array}{l}\text { Risk management } \\
\text { methods }\end{array}$ & $\begin{array}{l}\text { Assessment of risk } \\
\text { factors, probabilistic } \\
\text { indicators, and trends } \\
\text { towards their reduction }\end{array}$ & $\begin{array}{l}\text { The approach is } \\
\text { focused on eliminating } \\
\text { flaws, requires a } \\
\text { complex mathematical } \\
\text { apparatus }\end{array}$ & $\begin{array}{l}\text { Statistical and } \\
\text { probabilistic } \\
\text { calculations in } \\
\text { relation to the } \\
\text { identified } \\
\text { vulnerabilities; } \\
\text { analysis } \\
\end{array}$ \\
\hline 5 & $\begin{array}{l}\text { Macroeconomic } \\
\text { analysis in the } \\
\text { interpretation of } \\
\text { Industry } 4.0\end{array}$ & $\begin{array}{l}\text { "Yes / no" or rating score } \\
\text { of } 65 \text { parameters, divided } \\
\text { into } 9 \text { semantic groups }\end{array}$ & \begin{tabular}{lr}
\multicolumn{2}{l}{ The complexity of the } \\
analytical apparatus; \\
comparison \\
$\begin{array}{l}\text { overly } \\
\text { standards }\end{array}$
\end{tabular} & 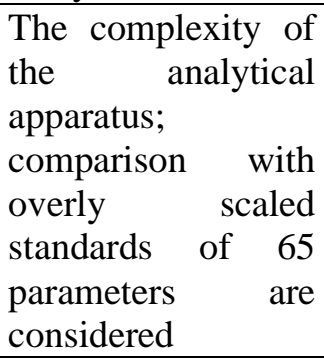 \\
\hline 6 & $\begin{array}{l}\text { Effort-Result } \\
\text { Comparison } \\
\text { Method }\end{array}$ & $\begin{array}{l}\text { Mathematically weighted } \\
\text { comparison of useful } \\
\text { effects and resources for } \\
\text { their achievement }\end{array}$ & $\begin{array}{l}\text { The result is highly } \\
\text { dependent on the } \\
\text { accuracy of the } \\
\text { mathematical "scales" } \\
\text { assigned by the analyst }\end{array}$ & $\begin{array}{l}\text { Matrix of } 8 \text { or more } \\
\text { indicators defined } \\
\text { by the analyst }\end{array}$ \\
\hline 7 & Author's methods & $\begin{array}{l}\text { Applied analysis of the } \\
\text { areas of activity involved } \\
\text { in DT, considering the } \\
\text { analyst's previous } \\
\text { experience }\end{array}$ & $\begin{array}{l}\text { The application of the } \\
\text { method is limited to } \\
\text { the professional } \\
\text { specialization of the } \\
\text { analyst; methods are } \\
\text { not disclosed }\end{array}$ & $\begin{array}{l}\text { Depends on the } \\
\text { method }\end{array}$ \\
\hline 8 & $\begin{array}{l}\text { Specialized } \\
\text { methods }\end{array}$ & $\begin{array}{l}\text { Analytical solution for a } \\
\text { single business case } \\
\text { (usually quick and / or } \\
\text { simplified) }\end{array}$ & $\begin{array}{l}\text { Methods are case- } \\
\text { specific and cannot be } \\
\text { applied by analogy }\end{array}$ & $\begin{array}{l}\text { Depends on the } \\
\text { method }\end{array}$ \\
\hline
\end{tabular}


When using qualitative and mixed assessment methods, quantitative indicators are used not necessarily, but as necessary - that is, at the discretion of the analyst or in accordance with the requirements of the methodology. Qualitative methods are distinguished by the fact that the performance indicators are derived. This means that the analyst assigns a "qualitative" value for a given block of economic data. The analysed data are selected either directly by the analyst among those admissible in the valuation model, or directly provided for in a specific valuation model (a situation typical for author's and intracorporate models).

From table 1 we can see, that qualitative and «mixed» methods prevail among approaches to assessing the effectiveness of digital transformation. This is largely due to the fact that digital transformation is associated not only with a direct increase in financial performance. The positive effect of digital transformation can be manifested in improving the organizational structure, improving the quality of management and the products themselves, preventive risk prevention and other characteristics that do not lend themselves to obvious material expression. In addition, the digital transformation of one business process can affect a number of other related processes, which will lead to a systemic effect that is also not clearly amenable to an unambiguous material assessment. Based on this, the analysis of digital transformation strictly in the context of investment analysis or bookkeeping value of assets can lead to misinterpretation of the effect, evaluating the project as financially unprofitable.

According to the PRCA consulting agency, in 2020 the average percentage of the marketing budget of companies for promoting products and related services online is about $25 \%$, and an annual increase of $10 \%$ is planned [2]. The key trends in the promotion of products in the digital environment include [5-6]:

- the use of smart devices to collect data on consumers purchasing industrial electronics;

- use of radio frequency identification of goods (RFID / Radio Frequency IDentification / -marks) when designing logistics flows for a group of companies;

- introduction of virtual reality (VR) and augmented reality (AR) technologies when presenting prototypes of products to a potential customer;

- combining the functionality of a PR-specialist for working with hybrid media and SMM (Social Media Marketing) -specialist.

Business transformation leads to changes in human resource management and the introduction of the concept of "neuromarketing" into practice. Neuromarketing is an interdisciplinary direction in science, formed at the intersection of neuroscience, psychology and marketing, exploring the cognitive and emotional aspects of the personality associated with organizational management.

In the digital economy, field data no longer provide an objective picture of customer preferences and potential choices, which is why new professions such as coordinator in distributed communities, foresight, coordinator of digital community development programs and corporate anthropologist are emerging.

In the field of human resource management, the concept of HR-digitalization arises. The basis is the Vuk model (V.U.K.A. - Volatity, Uncertainty, Complexity, Ambiguity), which determines the specifics of decision-making on managing an organization in an unstable external environment, the uncertainty of the actions of market players, the complexity of processes and the unclear assessment of what is happening on the part of experts. The company is transforming its business model, changing its product focus to technology. In the context of the digitalization of the economy, it becomes necessary to develop a digital strategy that determines the portfolio of the company's IT assets used.

When managing personnel, the basis is the PISA model, which involves paying attention when developing a strategy to such elements as:

1. Productivity. HR specialist must measure and continuously improve the productivity of each employee of the organization, the ultimate goal is to increase the income per employee;

2. Innovation (innovation) - HR should stimulate the introduction of process innovations in the practice of the organization, since they increase the economic added value by 5 times in comparison with the increase in labor productivity [7];

3. Speed is a competitive advantage in the market is gained by the industrial organization that quickly catches trends in changing consumer preferences, therefore leadership is associated with constant training of employees;

4. Adaptiveness in the modern world, continuous adaptation to changing environmental conditions and rapid scalability of IT solutions is of paramount importance [8-9]. 
The dominant trend in human resource management in the context of the digitalization of the economy is taking into account the worldview of generation Y (which in 2020 constitute $40 \%$ of the labor market), including:

- transformation of an HR person into a real business partner;

- the use of corporate mobile applications in the management of personnel recruiting processes;

- adherence to the concept of freedom (achieving a balance between professional implementation and personal life, work in remote access conditions and in several places).

Along with HR departments, personnel development structures are allocated, the task of which will include the management of employee talent and involvement in management processes, as well as digital divisions headed by directors for digital transformation. According to analysts' forecasts, specialists such as economists, managers and financiers will move to HR units by 2023 as their digital competencies in the field of personnel management develop [2].

Thus, for a full-fledged digital transformation, an organization needs to digitize the maximum number of elements that make up its business model. Given the specificity of DT associated with its complex nature, the use of "mixed" approaches seems to be a priority for assessing digital transformation: quantitative methods are insufficiently representative, and qualitative methods do not meet the required level of objectivity of analytical conclusions.

Conclusions and prospects for further research. Consideration of digital transformation is advisable not only in the context of studying the improvement of business models within the framework of developing digital technologies, but also from an applied point of view: what economic effects are achieved due to digital transformation and how much it is justified from a cost perspective.

The digital rethinking of business is driven by a clear digital strategy supported and led by leaders who drive digital culture and shape the new business environment in the digital economy. This is critical because in the future all business strategies will be digital strategies.

The purpose of further research is to study business strategies according to different type of enterprises.

\section{Sources and literature}

1. Закон України «Про стимулювання розвитку цифрової економіки в Україні». Верховна Рада Украӥни URL: https://zakon.rada.gov.ua/laws/show/1667-20\#Text

2. Цифрова економіка: тренди, ризики та соціальні детермінанти: Центр Разумкова, Київ, 2020. URL: https://razumkov.org.ua/uploads/article/2020_digitalization.pdf

3. Sand R. HR and Cloud Computing: How the Cloud is Transforming HR. HR Technologist URL: https://www.hrtechnologist.com/articles/digital-transformation/hr-and-cloud-computing-how-the-cloud-istransforming-hr/

4. Мельник В. В. Формування концепції інформаційного менеджменту: сутність, задачі, основні напрями розвитку. Гуманітарний вісник Запорізької державної інженерної академії. 2012. № 49. С.122-134.

5. 5.Як цифрова трансформація допоможе розвитку вашої організації? Terrasoft. 2020. URL: https://www.terrasoft.ua/page/digital-transformation

6. Лісова Р.М. Вплив діджиталізації на бізнес-моделі: етапи та інструменти цифрової трансформації. Науковий вісник Ужгородського національного університету. 2019. № 24. С. 114-118.

7.Звіт Глобального центру з цифрової трансформації бізнесу: Digital Vortex. How Digital Disruption Is Redefining Industries. Global Center for Digital Business Transformation URL: https://www.cisco.com/c/dam/en/us/solutions/collateral/industry-solutions/digital-vortex-report.pdf.

8.Aharon D., Bisson P., Bughin J., Chui M., Dobbs R., Manyika J., Woetzel J. The Internet of Things: Mapping the Value Behind the Hype. McKinsey Global Institute., June 2015. URL: https://www.mckinsey.com.

9.Гончар В., Бочаров О., Онофрийчук О. Інформаційно-комунікаційні системи забезпечення управлінських рішень. Центральноукраӥнський науковий вісник. Економічні науки. 2019. № 3(36). С. $255-264$.

\section{References:}

1.Zakon Ukrayiny «Pro stymulyuvannya rozvytku tsyfrovoyi ekonomiky v Ukrayini». Verkhovna Rada Ukrayiny Available at:https://zakon.rada.gov.ua/laws/show/1667-20\#Text [in Ukrainian].

2.Tsyfrova ekonomika: trendy, ryzyky ta sotsial'ni determinanty (2020): Razumkov centre, Київ. Available at: https://razumkov.org.ua/uploads/article/2020_digitalization.pdf [in Ukrainian]. 
3.Sand R. HR and Cloud Computing: How the Cloud is Transforming HR. HR Technologist. Available

at: https://www.hrtechnologist.com/articles/digital-transformation/hr-and-cloud-computing-how-the-cloud-istransforming-hr/

4.Mel'nyk V. V. (2012) Formuvannya kontseptsiyi informatsiynoho menedzhmentu: sutnist', zadachi, osnovni napryamy rozvytku [Formation of the concept of information management: essence, tasks, main directions of development]. Humanitarnyy visnyk Zaporiz'koyi derzhavnoyi inzhenernoyi akademiyi, 49, 122-134 [in Ukrainian].

5.Yak tsyfrova transformatsiya dopomozhe rozvytku vashoyi orhanizatsiyi? [How will the digital transformation help the development of your organization?] (2020) Terrasoft. Availableat: https://www.terrasoft.ua/page/digital-transformation [in Ukrainian].

6. Lisova R.M. (2019) Vplyv didzhytalizatsiyi na biznes-modeli: etapy ta instrumenty tsyfrovoyi transformatsiyi [The impact of digitalization on business models: stages and tools of digital transformation]. Naukovyy visnyk Uzhhorods'koho natsional'noho universytetu, 24. 114-118 [in Ukrainian].

7. Zvit Hlobal'noho tsentru z tsyfrovoyi transformatsiyi biznesu: Digital Vortex. How Digital Disruption Is Redefining Industries. Global Center for Digital Business Transformation Available at: https://www.cisco.com/c/dam/en/us/solutions/collateral/industry-solutions/digital-vortex-report.pdf [in Ukrainian].

8. Aharon D., Bisson P., Bughin J., Chui M., Dobbs R., Manyika J., Woetzel J. The Internet of Things: Mapping the Value Behind the Hype. McKinsey Global Institute., June 2015. URL: https://www.mckinsey.com.

9. Gonchar V., Bohachov O., Onofriichuk O. (2019) Informatsiyno-komunikatsiyni systemy zabezpechennya upravlins'kykh rishen' [Information and communication systems for management decisions]. Tsentral'noukrayins'kyy naukovyy visnyk. Ekonomichni nauky, 3(36), 255-264 [in Ukrainian].

Стаття надійшла до редакції 20.08.2021 р. 